\title{
Effects of the condylar process fracture on facial symmetry in rats submitted to protein undernutrition ${ }^{1}$
}

\author{
Efeitos da fratura do processo condilar na simetria facial em ratos submetidos à desnutrição \\ protéica
}

\author{
Lucimar Rodrigues', Luciana CorrêaII, João Gualberto de Cerqueira Luz ${ }^{\mathrm{III}}$
}

${ }^{1}$ Research performed at Experimental Laboratory of Department of Maxillofacial Surgery, Prosthetics and Traumatology, School of Dentistry, University of Sao Paulo (USP), Brazil. Part of thesis. Tutor: Prof. Dr. João Gualberto de Cerqueira Luz.

\begin{abstract}
${ }^{\mathrm{I}}$ Fellow PhD Degree, Postgraduate Program in Oral and Maxillofacial Surgery, Department of Oral and Maxillofacial Surgery, Division of Maxillofacial Traumatology, School of Dentistry, USP, Sao Paulo-SP, Brazil. Conception and outlining of the study and responsible for intellectual and scientific containts of the article. Acquisition and interpretation of data Manuscript writing. Statistical analysis.

${ }^{\text {II }} \mathrm{PhD}$, Assistant Professor, Department of Stomatology, Division of General Pathology, School of Dentistry, USP, Sao Paulo-SP, Brazil. Acquisition and interpretation of data. Critical revision. Resource captivation.

${ }^{\text {III }} \mathrm{PhD}$, Associate Professor, Department of Oral and Maxillofacial Surgery, Division of Maxillofacial Traumatology, School of Dentistry, USP, Sao Paulo-SP, Brazil. Manuscript writing. Critical revision. Statistical analysis. Responsible for English language.
\end{abstract}

\begin{abstract}
Purpose: To investigate the facial symmetry of rats submitted to experimental mandibular condyle fracture and with protein undernutrition ( $8 \%$ of protein) by means of cephalometric measurements. Methods: Forty-five adult Wistar rats were distributed in three groups: fracture group, submitted to condylar fracture with no changes in diet; undernourished fracture group, submitted to hypoproteic diet and condylar fracture; undernourished group, kept until the end of experiment, without condylar fracture. Displaced fractures of the right condyle were induced under general anesthesia. The specimens were submitted to axial radiographic incidence, and cephalometric mensurations were made using a computer system. The values obtained were subjected to statistical analyses among the groups and between the sides in each group. Results: There was significative decrease of the values of serum proteins and albumin in the undernourished fracture group. There was deviation of the median line of the mandible relative to the median line of the maxilla, significative to undernutrition fracture group, as well as asymmetry of the maxilla and mandible, in special in the final period of experiment. Conclusion: The mandibular condyle fracture in rats with proteic undernutrition induced an asymmetry of the mandible, also leading to consequences in the maxilla.
\end{abstract}

Key words: Mandibular Condyle. Facial Asymmetry. Protein-Energy Malnutrition. Rats.

\section{RESUMO}

Objetivo: Investigar a simetria facial de ratos submetidos à fratura experimental de côndilo mandibular e com desnutrição protéica ( $8 \%$ de proteína) por meio de mensurações cefalométricas. Métodos: 45 ratos Wistar adultos foram distribuídos em três grupos: grupo fraturado, submetido a fratura condilar sem alteração na dieta; grupo fraturado desnutrido, submetido a dieta hipoprotéica e fratura condilar; grupo desnutrido, mantido até o final do experimento, sem fratura condilar. Fraturas com desvio foram feitas no côndilo direito com anestesia geral. Os espécimes foram submetidos à incidência radiográfica axial, e mensurações cefalométricas foram feitas por meio de um sistema de computador. Os valores obtidos foram submetidos a análises estatísticas entre os grupos e entre os lados em cada grupo. Resultados: Houve redução significante nos valores de proteínas séricas e de albumina no grupo fraturado desnutrido. Houve desvio da linha média da mandíbula em relação à linha média da maxila, significativo no grupo fraturado desnutrido, assim como assimetria da maxila e da mandíbula, em especial no final do período experimental. Conclusão: A fratura do côndilo mandibular em ratos com desnutrição protéica induziu uma assimetria na mandíbula, também com consequências na maxila. Descritores: Côndilo Mandibular. Assimetria Facial. Desnutrição Proteico-Energética. Ratos. 


\section{Introduction}

Condylar process fractures are common, most often unilaterally with medial deviation ${ }^{1,2}$. A favourable prognosis when treated by closed methods has been described ${ }^{2,3}$. Also, remodelling of condylar processes following conservative treatment has been radiographically demonstrated ${ }^{3,4}$. However, there are some concern regarding skeletal changes, represented by mandibular asymmetry, mainly in young individuals ${ }^{5,6}$. An experimental study in young rats, in which an unilateral, deviated subcondilar fracture was induced, demonstrated a tendency of deviation of the mandible to the fracture side, but without significant difference between experimental and sham-operated animals ${ }^{7}$.

Protein-energy malnutrition affects approximately half of the population worldwide, especially in developing countries $^{8}$. Fracture healing consists of a complex series of cell events demanding a high protein synthesis rate ${ }^{9}$. The damaging effects of protein undernutrition on callus formation, leading to nonunion and intermediate bone healing, have been experimentally demonstrated ${ }^{9}$.

Mandibular condyle fractures present a complex healing process, which includes callus formation and joint recovery with condylar repositioning ${ }^{7,10}$. Studies that experimentally induced such fractures have demonstrated heavy weight loss, as well as mandible deviation and restricted mouth opening ${ }^{7,11}$. However, the significance of this condition to the healing process and skeletal changes is poorly understood.

The purpose of this study was to investigate the facial symmetry of rats submitted to experimental mandibular condyle fracture and with protein undernutrition by means of cephalometric measurements.

\section{Methods}

Forty-five adult male Wistar rats were used and distributed in three groups of 15 animals: fracture group, submitted to condylar fracture with no changes in diet; undernourished fracture group, submitted to hypoproteic diet and condylar fracture; undernourished group, without condylar fracture. The study was approved by the local committee on research ethics.

Undernourished fracture animals were fed a hypoprotein diet ( $8 \%$ of proteins) during a month previously to condylar fracture. Undernourished only animals had this diet kept until the end of experiment, without fracture. Hypoprotein diet was prepared in our laboratory, with $8 \%$ of proteins ${ }^{12}$ and vitamins and minerals maintained according to the American Institute of Nutrition to AIN-93G recommendations for rodent diets ${ }^{13}$. Fracture only animals were fed an ordinary diet of rodent feed (Labina, Agribands Purina, Sao Paulo, Brazil) which contains $23 \%$ of proteins and levels of carbohydrates, lipids, minerals, and vitamins accordingly AIN-93G recommendations. Both the diets were administered in powder form for one week postoperatively, and in regular form in the remaining period.

The animals of the fracture groups were submitted to general anesthesia, induced by xylazine $(0.01 \mathrm{ml} / \mathrm{kg})$ and ketamine $(0.1 \mathrm{ml} / \mathrm{kg})$. A preauricular incision of $1 \mathrm{~cm}$ was made on the right side, followed by blunt dissection through the masseter muscle, just below the zygomatic arch. Condylar process was exposed, and fracture was achieved by using a mosquito (Halstead) forceps, and the condylar fragment was deviated medially ${ }^{7}$. Care was taken so as not to damage the articular surfaces. Suture in layers concluded the procedure.

The animals were sacrificed after 24h, 1 week, 2 week, 1 month and 3 months. Their body weights were recorded at the first day of experiment and at the sacrifice. At sacrifice blood samples were colleted, and total serum proteins and serum albumin were determined by colorimetric method (Labtest Kit, Labtest, Brazil) and spectrophotometer (35 D, Coleman, Brazil). These were used as undernutrition indicatives ${ }^{14,15}$. To evaluate the significance of differences among the mean values of all the groups, analysis of variance was used $(\mathrm{p}<0.050)$.

After fixing in formalin for one week, radiographs of the skull in axial (dorsoventral) projection were obtained. Care was taken to mantain the horizontal and vertical planes. The radiographs were produced using a standard dental machine at $56 \mathrm{kV}$ and $10 \mathrm{~mA}$, with an exposure time of $0.4 \mathrm{~s}$. A constant $40 \mathrm{~cm}$ focus-to-film distance was maintained and periapical film was used.

The radiographic images were digitized, and measurements obtained with Imagelab software. Angular measurements of deviation of the mandible, with reference to a line between both tympanic bullae (angle $\AA$ ) were registered (Figure 1). The following distances were measured bilaterally: TB - IF - tympanic bulla to infraorbital foramen; IF - IP infraorbital foramen to incisal point; AP - II -angular process to insertion of incisor; and AP - IP - angular process to incisal point (Figure 2 ).

To evaluate possible differences among the three groups, analysis of variance (ANOVA) and Tukey"s test or Dunnett's test were used. In the comparison among periods by group, Friedman's test was used, and when there was significance, the paired Student's t-test was used. The significance level was set at $5 \%(\mathrm{p}<0.050)$.

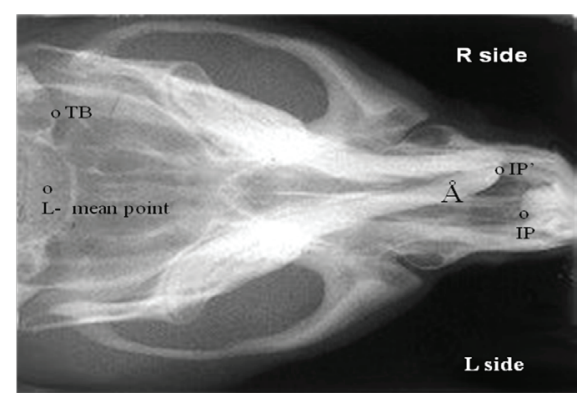

FIGURE 1 - Axial radiograph of the skull. TB = tympanic bulla, IP = incisal point of maxilla, IP' $=$ incisal point of mandible, $\mathbf{L}=$ medial point, $\AA$ = angle 


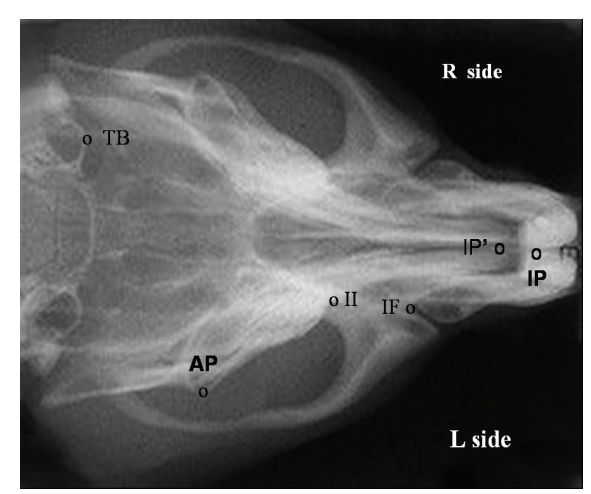

FIGURE 2 - Axial radiograph of the skull. $\mathbf{T B}=$ tympanic bulla, IP $=$ incisal point of maxilla, IP'= incisal point of mandible, $\mathbf{A P}=$ angular process, $\mathbf{I I}=$ insertion of incisor, $\mathbf{I F}=$ infraorbital foramen.

\section{Results}

There was significative decrease, mainly in the initial periods, of the values of serum proteins and albumin in the undernourished fracture group. Mean values of total serum protein $(\mathrm{g} / \mathrm{dL})$ according to each group were: 24 hours, fracture $=8.4 \pm 2.0$, undernourished fracture $=5.1 \pm 0.7$ and undernourished $=5.2 \pm 0.8(\mathrm{p}=0.036) ; 1$ month, fracture $=8.9$ \pm 2.1 , undernourished fracture $=3.9 \pm 0.7$ and undernourished $=7.3 \pm 1.2(\mathrm{p}=0.015)$. Mean values of serum albumin $(\mathrm{g} / \mathrm{dL})$ according to each group were: 24 hours, fracture $=3.1 \pm 0.7$, undernourished fracture $=5.1 \pm 0.7$ and undernourished $=1.9$ $\pm 0.5(\mathrm{p}=0.043) ; 1$ month, fracture $=2.8 \pm 0.1$, undernourished fracture $=1.7 \pm 0.2$ and undernourished $=2.3 \pm 0.9(p=0.125)$.

Mensuration of angle Å revealed an increase of deviation in the 15 days period in the fracture and undernourished fracture groups, and a higher deviation in the three months period in the undernourished fracture group. The mean values of angle $\AA$ according to the experimental period are presented in Figure 3. In the comparison of angle $\AA$ measurements among groups, the ANOVA demonstrated that there were differences in one week, one month and three months periods. With the use of Tukey's or Dunnett's tests there was significant difference between undernourished fracture and fracture groups, as well as between undernourished fracture and undernourished groups in the three months period (Table 1). Also, with use of Friedman's test there was significant difference in the undernourished fracture group $(\mathrm{p}=0.043)$, and paired Student's t-test showed significant difference between 24 hours and three months $(p=0.001)$, one week and three months $(p=0.006)$, and one month and three months $(\mathrm{p}<0.001)$

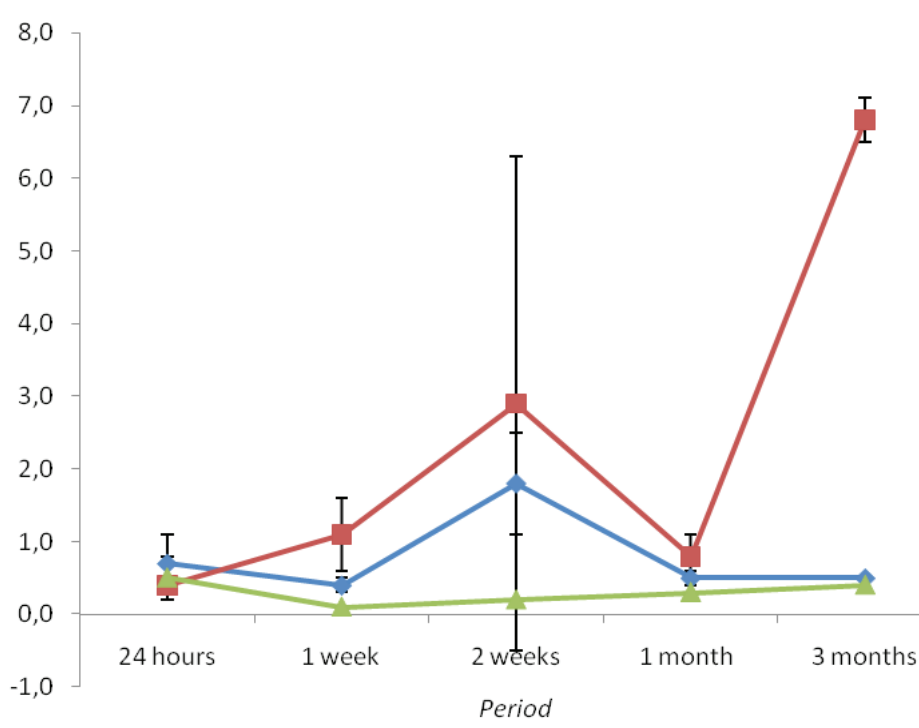

$\longrightarrow$ Fracture $\rightarrow$ Undernourished fracture $\rightarrow$ Undernourished

FIGURE 3 - Mean values (degrees) of Angle $\AA$ of all the groups according to the experimental period.

TABLE 1 - Significance of the analysis of variance of angle $\AA$ measurements

\begin{tabular}{lcccc}
\hline & & \multicolumn{3}{c}{ Group and Tukey's or Dunnett's tests } \\
\cline { 3 - 5 } Period & $\mathrm{p}$ value & Fracture & Undernourished fracture & Undernourished \\
\hline \multirow{2}{*}{24 hours } & 0.494 & - & - & - \\
1 week & 0.014 & $\mathrm{a}$ & $\mathrm{a}$ & $\mathrm{a}$ \\
2 weeks & 0.336 & - & - & - \\
1 month & 0.038 & $\mathrm{a}$ & $\mathrm{a}$ & $\mathrm{a}$ \\
3 months & $<0.001$ & $\mathrm{a}$ & $\mathrm{b}$ & $\mathrm{a}$ \\
\hline
\end{tabular}

Distinct letters indicate statistically significant difference $(\mathrm{p}<0.050)$.

The mean values of the distances found on the mensurations of the maxilla of all the groups according to the experimental period are presented in Figure 4. In the comparison of the maxillary measurements among groups, the ANOVA demonstrated that there as difference to the TB-IF, measurement in the period of three months, left side (Table 2). With the use of Tukey's or Dunnett's tests there was significant difference between undernourished fracture and fracture groups. The ANOVA demonstrated also that there were differences to the IFIP measurement in the period of one month on the left side, and in the period of three months on the right side (Table 2). With the use of Tukey's or Dunnett's tests there was no significant difference between groups in on month on the left side, and there was significant difference between undernourished fracture and undernourished groups on the right side. Also with use of Friedman's test there was no significant difference in all the groups to both measurements. Paired Student's t-test showed significant difference to the TB-IF measurement in the undernourished fracture group at three months between right and left sides ( $p=0.029)$, as well as to the IF-IP measurement in the undernourished fracture group at two weeks between right and left sides $(p=0.016)$, and in the fracture group at three months 
between right and left sides $(\mathrm{p}=0.005)$.

The mean values of the distances found on the measurement of the mandible of all the groups according to the experimental period are presented in Figure 5. In the comparison of the mandibular measurements among groups, the ANOVA demonstrated that there was difference to the AP-II measurement in the period of three months, left side (Table 3). With the use of Tukey's or Dunnett's tests there was no significant difference between groups. The ANOVA demonstrated also that there were differences to the AP-IP measurement in the period of three months, right side and left side (Table 3). With the use of Tukey's or Dunnett's tests there was significant difference between undernourished fracture and undernourished groups on the right side, and between undernourished fracture and fracture groups, undernourished fracture and undernourished groups, as well as fracture and undernourished groups on the left side. Also, with use of Friedman's test there was no significant difference in all the groups to both measurements. Paired Student's t-test showed significant difference to the AP-II measurement in the undernourished fracture group at two weeks between right and left sides $(\mathrm{p}=0.037)$, and at three months between right and left sides $(p=0.010)$, as well as to the AP-IP measurement in the undernourished fracture group at one month between right and left sides $(p=0.036)$, and in the undernourished group at three months between right and left sides $(\mathrm{p}=0.048)$.

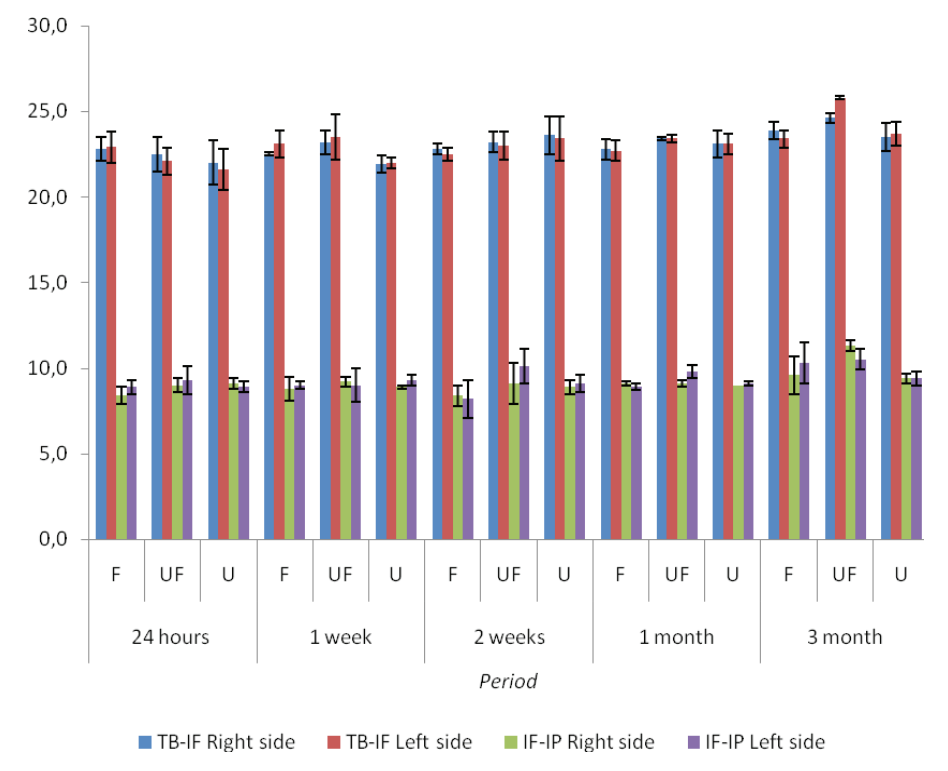

FIGURE 4 - Mean values $(\mathrm{mm})$ of the distances found on the maxilla of all the groups according to the experimental period $(\mathbf{T B}=$ tympanic bulla, $\mathbf{I F}=$ infraorbital foramen, $\mathbf{I P}=$ incisal point of the maxilla, $\mathbf{F}=$ fracture group, $\mathbf{U F}=$ undernourished fracture group, $\mathbf{U}=$ undernourished group).

TABLE 2 - Significance of the analysis of variance of the measurements of the maxilla

Group and Tukey's or Dunnett's tests

\begin{tabular}{|c|c|c|c|c|c|c|}
\hline Measurement & Side & Period & $p$ value & Fracture & Undernourished fracture & undernourished \\
\hline \multirow{10}{*}{$\mathrm{TB}-\mathrm{IF}$} & \multirow{5}{*}{ Right } & 24 hours & 0.674 & - & - & - \\
\hline & & 1 week & 0.076 & - & - & - \\
\hline & & 2 weeks & 0.443 & - & - & - \\
\hline & & 1 month & 0.462 & - & - & - \\
\hline & & 3 months & 0.128 & - & - & - \\
\hline & \multirow{5}{*}{ Left } & 24 hours & 0.354 & - & - & - \\
\hline & & 1 week & 0.188 & - & - & - \\
\hline & & 2 weeks & 0.576 & - & - & - \\
\hline & & 1 month & 0.253 & - & - & - \\
\hline & & 3 months & 0.003 & a & $b$ & $a b$ \\
\hline \multirow{10}{*}{ IF - IP } & \multirow{5}{*}{ Right } & 24 hours & 0.154 & - & - & - \\
\hline & & 1 week & 0.641 & - & - & - \\
\hline & & 2 weeks & 0.508 & - & - & \\
\hline & & 1 month & 0.446 & - & - & - \\
\hline & & 3 months & 0.030 & $a b$ & a & $b$ \\
\hline & \multirow{5}{*}{ Left } & 24 hours & 0.699 & - & - & - \\
\hline & & 1 week & 0.795 & - & - & - \\
\hline & & 2 weeks & 0.110 & - & - & - \\
\hline & & 1 month & 0.021 & a & a & $a$ \\
\hline & & 3 months & 0.204 & - & - & - \\
\hline
\end{tabular}

Distinct letters indicate statistically significant difference $(\mathrm{p}<0.050)$. 


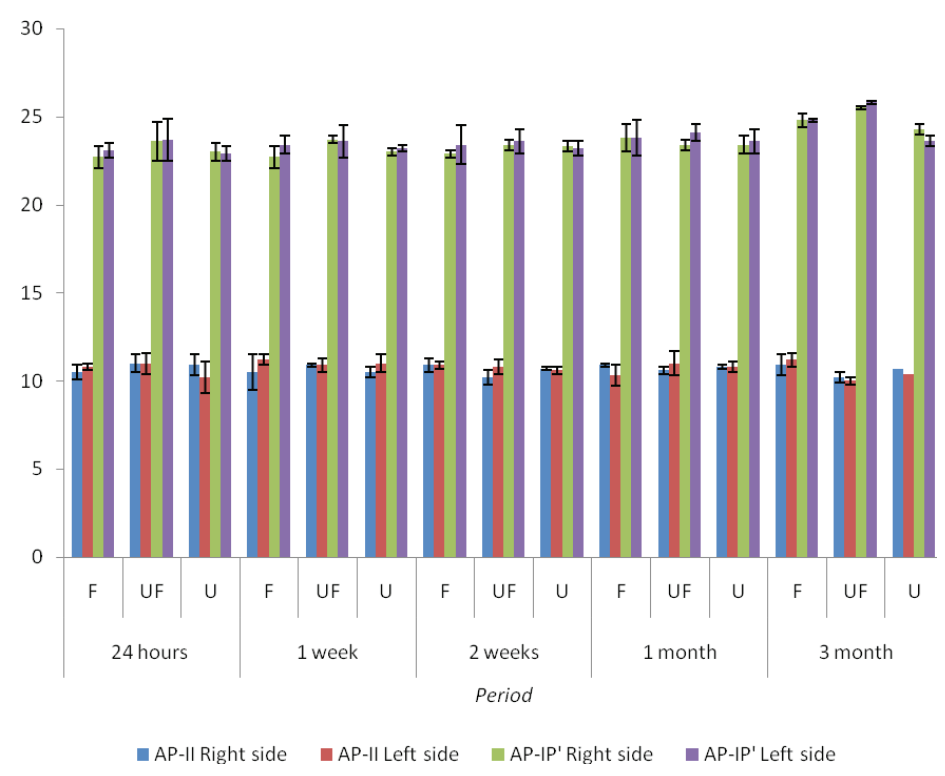

FIGURE 5 - Mean values $(\mathrm{mm})$ of the distances found on the mensurations of the mandible of all the groups according to the experimental period $(\mathbf{A P}=$ angular process, $\mathbf{I I}=$ insertion of incisor of the mandible, $\mathbf{I P}=$ incisal point, $\mathbf{F}=$ fracture group, $\mathbf{U F}=$ undernourished fracture group, $\mathbf{U}=$ undernourished group).

\section{Discussion}

In this study mandibular condyle fractures were induced in rats with protein undernutrition, and cephalometric mensurations focused on facial symmetry. The final result was an asymmetry of the mandible, also with asymmetry of the maxilla. Two models were used in this study. The condylar fracture, unilateral and medially displaced ${ }^{7,10}$, follows the most frequent form of mandibular condyle fracture ${ }^{1,2}$. After condylar fracture, the animals may consume rodent feed during experiment, allowing maintenance of them during the study period ${ }^{7,10}$. Protein undernutrition has been successfully induced by a specially prepared hypoprotein $\operatorname{diet}^{12}$. A significant decrease in the values of serum proteins and albumin in the same group were indicators of undernutrition ${ }^{14,15}$. Similar findings have been reported by a study of tibial fracture healing in protein malnutrition ${ }^{9}$.

Cephalometric evaluations from radiographs of dissected specimens using a computer system lead to reliable measurements, reducing technical difficulties ${ }^{16}$. Distances found were similar to those noted in other experiments ${ }^{17-20}$. Only structures which do not underwent direct influence of the fracture were used as reference points ${ }^{16,18,19}$.

In this study deviation of the median line of the mandible in relation to the maxillary median line was observed in the fracture and undernourished fracture groups. An angle mensuration, with reference to the cranial base, called angle $\AA$, was used to determine the occurrence of deviation ${ }^{7,18}$. Other experimental studies have demonstrated the occurrence of asymmetries after condylar fractures through macroscopic

TABLE 3 - Significance of the analysis of variance of the measurements of the mandible

Group and Tukey's or Dunnett's tests

\begin{tabular}{|c|c|c|c|c|c|c|}
\hline Measurement & Side & Period & $p$ value & Fracture & Undernourished fracture & undernourished \\
\hline \multirow{10}{*}{ AP - II } & \multirow{5}{*}{ Right } & 24 hours & 0.440 & - & - & - \\
\hline & & 1 week & 0.637 & - & - & - \\
\hline & & 2 weeks & 0.113 & - & - & - \\
\hline & & 1 month & 0.077 & - & - & - \\
\hline & & 3 months & 0.213 & - & - & - \\
\hline & \multirow{5}{*}{ Left } & 24 hours & 0.436 & - & - & - \\
\hline & & 1 week & 0.563 & - & - & - \\
\hline & & 2 weeks & 0.564 & - & - & - \\
\hline & & 1 month & 0.169 & - & - & - \\
\hline & & 3 months & 0.027 & a & a & a \\
\hline \multirow{10}{*}{ AP - IP } & \multirow{5}{*}{ Right } & 24 hours & 0.410 & - & - & - \\
\hline & & 1 week & 0.119 & - & - & - \\
\hline & & 2 weeks & 0.181 & - & - & - \\
\hline & & 1 month & 0.639 & - & - & - \\
\hline & & 3 months & 0.006 & $a b$ & a & $b$ \\
\hline & \multirow{5}{*}{ Left } & 24 hours & 0.443 & - & - & - \\
\hline & & 1 week & 0.766 & - & - & - \\
\hline & & 2 weeks & 0.537 & - & - & - \\
\hline & & 1 month & 0.683 & - & - & - \\
\hline & & 3 months & $<0.001$ & a & b & c \\
\hline
\end{tabular}

Distinct letters indicate statistically significant difference $(\mathrm{p}<0.050)$. 
observations $^{21}$. A previous condylar fracture with deviation has been associated to mandibular asymmetries, in special during growth period ${ }^{22}$. An experimental study demonstrated the occurrence of asymmetry of the mandible associated to degenerative changes of the condyle after displaced condylar process fracture in growing rats ${ }^{20}$.

Another representative finding was a small length of the maxilla on the same side of the fracture, as well as a small length of the mandible on the same side of the fracture, verified in the undernourished fracture group. Thus, the effects of the condylar fracture were significative in the undernourished fracture group, demonstrated by asymmetry of the maxilla and mandible, in special in the final period of experiment. Nocive effects of protein undernutrition on callus formation have been demonstrated in long bone experimental fractures ${ }^{9}$. The possibility of maxillary growth influencing mandibular growth and vice versa by occlusal intercuspation has been described ${ }^{23}$. Occlusal disturbances have been considered the main cause of asymmetry of the midface after condylar fractures in rabbits ${ }^{24}$. The capacity of the condylar fracture to induce asymmetries of the maxilla and mandible has been verified in other studies, and a compensation of the masticatory function through a neuromuscular mechanism could influence this process ${ }^{20,23,25}$.

\section{Conclusion}

The effects of the condylar process fracture on facial symmetry in rats submitted to protein undernutrition, when compared to only fracture and undernourished groups, were deviation of the median line of the mandible, as well as asymmetry of the maxilla and mandible, in special in the final period of experiment.

\section{References}

1. Silvennoinen U, lizuka T, Lindqvist C, Oikarinen K. Different patterns of condylar fractures: an analysis of 382 patients in a 3-year period. J Oral Maxillofac Surg. 1992;50:1032-7.

2. Joss U, Kleinheinz J. Therapy of condylar neck fractures. Int $\mathbf{J}$ Oral Maxillofac Surg. 1998;27:247-54.

3. Feifel H, Albert-Deumlich J, Riediger D. Long-term follow-up of subcondilar fractures in children by electronic computer-assisted recording of condylar movements. Int J Oral Maxillofac Surg. 1992;21:70-6.

4. Luz JGC, Chilvarquer I. Remodeling of bilateral fractures of the mandibular condyle. Acta Stomatol Belg. 1996;93:167-70.

5. Hovinga J, Boering $G$, Stegenga B. Long term results of nonsurgical management of condylar fractures in children. Int $\mathrm{J}$ Oral Maxillofac Surg. 1999;28:429-40.

6. Strobl H, Emshoff R, Röthler G. Conservative treatment of unilateral condylar fractures in children: a long-term clinical and radiologic follow-up of 55 patients. Int J Oral Maxillofac Surg. 1999;28:95-8

7. Luz JG, Araújo VC. Rotated subcondylar process fracture in the growing animal: an experimental study in rats. Int $\mathrm{J}$ Oral Maxillofac Surg. 2001;30:545-9.

8. Mello ST, Liberti EA, Sant'Ana DM, Molinari SL, Miranda-Neto MH. Morphologic and quantitative study of myoenteric plexus of the duodenum of rats submitted the protein undernutrition diet and with privation of the complex B vitam. Acta Scientiarum. 2004;26:251-6
9. Guarniero R, Cinagava MY, Santana PJ, Batista MA, Oliveira LAA, Rodrigues CJ, Cinagava FT. Influência do componente protéico na consolidação de fraturas: trabalho experimental em ratos. Acta Ortop Bras. 2003;11:206-10.

10. Teixeira AC, Luz JG, Araújo VC, Araújo NS. Healing of the displaced condylar process fracture: an experimental study. J Cranio Maxillofac Surg. 1998;26:326-30.

11. Long X, Goss AN. A sheep model of intracapsular condylar fracture. J Oral Maxillofac Surg. 2007;65:1102-8.

12. Santos MAS, Ferraz MR, Teixeira CV, Sampaio FJB, Fontes Ramos C. Effects of undernutrition on serum and testicular testosterone levels and sexual function in adult rats. Horm Metab Res. 2004;36:27-33.

13. American Institute of Nutrition to AIN-93G recommendations for rodent diets; 1993.

14. De Leeuw I, Vandewoude M, Van Elst F. Nutritional assessment as a quality control of total parenteral nutrition. Acta Chir Belg. 1981;80:145-8.

15. Hughes MS, Kazmier P, Burd TA, Anglen J, Stoker AM, Kuroli K, Carson WL, Cook JL. Enhanced fracture and soft-tissue healing by means of anabolic dietary supplementation. J Bone Joint Surg Am. 2006;88:2386-94.

16. Del Campo AI, Elizondo MM, Magnelli LM, Valadez ASOntiveros DS. Craniofacial development in rats with early resection of the zygomatic arch. Plast Reconstr Surg. 1995;95:486-95.

17. Rocha EMVF, Goulart AC, Goldenberg S, Luz JGC. Efeitos da fratura de corpo da mandíbula no crescimento da maxila e da mandíbula. Estudo experimental em ratos jovens. Acta Cir Bras. 2002;17:102-9.

18. Rodrigues L, Luz JGC. Conseqüências da remoção do côndilo mandibular no crescimento da maxila e da mandíbula: estudo experimental em ratos. Acta Cir Bras. 2001;16:15-25.

19. Rodrigues L, Miyazaki LT, Luz JGCL. Conseqüências no crescimento de maxila e mandíbula de defeito ósseo cirúrgico no ramo da mandíbula de ratos. Acta Cir Bras. 2004;19:523-8.

20. Teixeira VCB, Teixeira ACB, Luz JGC. Skeletal changes after experimentally displaced condylar process fracture in growing rats. J Craniomaxillofac Surg. 2006;34:220-5.

21. Takatsuka S, Terai K, Yoshida K, Narinobou M, Ueki K, Nakagawa $\mathrm{K}$, Yamamoto E. A comparative study of unilateral dislocated mandibular condyle fractures in the rabbit. J Craniomaxillofac Surg. 2005;33:180-7.

22. Ayoub AF, Mostafa YA. Aberrant mandibular growth: theoritical implications. Am J Orthod Dentofacial Orthop. 1992;101:255-65.

23. Enlow DH. Facial growth, Philadelphia:.W B Saunders,3rd edition; 1990.

24. Altonen M, Ranta R, Ylipaavalniemi P. Midface deviation due to mandibular fractures. An experimental study clinical comparison. J Maxillofac Surg. 1978;6:143-7.

25. Proffit WR, Vig KWL, Turvey TA. Early fracture of the mandibular condyles: frequently an unsuspected cause of growth disturbances. Am J Orthod. 1980;78:1-24.

\section{Correspondence:}

Conflict of interest: none

Prof. Dr. João Gualberto de Cerqueira Luz

Depto. Cirurgia, Prótese e Traumatologia

Buco Maxilo Faciais

Faculdade de Odontologia - Universidade

de São Paulo

Av. Prof. Lineu Prestes, 2227

5508-900 São Paulo - SP Brasil

Phone: (55 11)3091-7887

jgcluz@usp.br

Received: September 20, 2010

Review: November 16, 2010

Accepted: December 14, 2010 